\title{
Macrophyte diversity in rivers and streams of the Vologda Region and several other regions of Russia
}

\author{
Dmitriy A. Philippov $¥, \S$, Aleksandra S. Komarova ${ }^{\ddagger}$ \\ ‡ Papanin Institute for Biology of Inland Waters Russian Academy of Sciences, Borok, Russia \\ $\S$ Tyumen State University, AquaBioSafe, Tyumen, Russia
}

Corresponding author: Dmitriy A. Philippov (philippov d@mail.ru)

Academic editor: Nina Filippova

Received: 23 Oct 2021 | Accepted: 01 Dec 2021 | Published: 03 Dec 2021

Citation: Philippov DA, Komarova AS (2021) Macrophyte diversity in rivers and streams of the Vologda Region and several other regions of Russia. Biodiversity Data Journal 9: e76947. https://doi.org/10.3897/BDJ.9.e76947

\section{Abstract \\ Background}

The data paper contains the authors' materials on the diversity of macrophytes, macroscopic plants regardless of their taxonomic position, in rivers and streams of East European Russia and Western Siberia. These data, collected on 247 rivers and 32 streams in 13 administrative regions of the Russian Federation, were provided as an occurrence dataset presented in the form of GBIF-mediated data. The main portion of the data was obtained in water objects of the Vologda Region (5201 occurrences). In addition, occurrences from the Arkhangelsk Region (347 occurrences), Khanty-Mansi Autonomous Okrug (159), Yaroslavl Region (132), Novgorod Region (97), Kostroma Region (41), Republic of Karelia (31), Sverdlovsk Region (29), Komi Republic (28), Orenburg Region (26), Chelyabinsk Region (22), Voronezh Region (22) and Tyumen Region (18) were given. The studies were carried out mainly in the southern and middle taiga and, to a lesser extent, in the northern taiga and the forest-steppe. The analysed watercourses belong to five drainage basins: the Azov Sea, the Baltic Sea, the White Sea, the Caspian Sea and the Kara Sea. The dataset contains materials on the diversity of Plantae (6094 occurrences) and Chromista (59 occurrences). This paper, in a standardised form, summarises mostly unpublished materials on the biodiversity of lotic ecosystems. 


\section{New information}

The paper summarises the data obtained in long-term studies of phytodiversity in a range of rivers and streams of East European Russia and, fragmentarily, Western Siberia. A total of 6153 occurrences were included in the dataset. According to the GBIF taxonomic backbone, the dataset comprises 292 taxa, including 280 lower-rank taxa (species, subspecies, varieties) and 12 taxa identified to the genus level. All the occurrences are published openly through the Global Biodiversity Information Facility (GBIF) for the first time. Most of the data were stored in field diaries and, thus, by adding the data in GBIF, we believe that other researchers could benefit from it.

\section{Keywords}

Russia, Eastern Europe, Western Siberia, dataset, macrophytes occurrences, flora of rivers, flora of streams, data paper, rare species

\section{Introduction}

Macrophytes are an essential component of lotic ecosystems, especially in terms of biodiversity (Chambers et al. 2008), playing an important functional role, providing trophic resources and habitat for other aquatic organisms (Biggs 1996, Grenouillet et al. 2002) and regulating water flows and their chemistry (e.g. Carpenter and Lodge 1986, Clarke and Wharton 2001, Horvath 2004, Gurnell et al. 2006). Under the Water Framework Directive (European Commision 2000), macrophytes are one of the key indicators used for environmental health assessment.

The study summarises the authors' materials collected in the rivers of the European part of Russia between 2005 and 2021 and Western Siberia in 2021. A small part (5.5\%) of the data was published in the research articles (Ivicheva et al. 2018, Chernova and Philippov 2019, Chernova et al. 2019), but mainly as short notes on the new records (Dulin et al. 2009, Afonina et al. 2010, Dulin and Philippov 2010, Abolin et al. 2011, Bobrov and Philippov 2012, Sofronova et al. 2012, Chemeris and Bobrov 2013, Chemeris et al. 2013, Shabunov and Philippov 2014, Sofronova et al. 2015, Vishnyakov and Philippov 2018, Vishnyakov et al. 2020, Vishnyakov et al. 2021).

All the raw data on the biodiversity in rivers and streams are provided in an occurrence dataset (Philippov and Komarova 2021).

\section{Project description}

Title: Diversity, distribution, ecology, biology of aquatic and semi-aquatic plants in the European North

Personnel: Dmitriy A. Philippov 


\section{Sampling methods}

Study extent: A list of records of macrophytes in rivers and streams of European Russia and Western Siberia is presented. By macrophytes, we understood macroscopic plants, regardless of their taxonomic position and ecological characteristics. Macrophytes include vascular plants, mosses, liverworts and large multicellular algae (Papchenkov et al. 2003). We determined the flora of rivers and streams as aquatic species and species directly related to the aquatic environment (helophytes, plants of the water's edge, amphibious plants, hygrophytes, plants of drying sandbanks).

Sampling description: Field studies were carried out from May to October, mainly during the greatest development of macrophytes (July and August). The composition of the flora of rivers and streams was established during route field studies. We studied all available microhabitats in the channel and coastal parts of water bodies, including those differing in current velocity, sediments, depths and macrophyte canopy development. When studying streams, the route, as a rule, ranged from 50 to $150 \mathrm{~m}$; on rivers, usually from 100 to 1000 $\mathrm{m}$. In the Vologda Region, studies were carried out in all landscapes; several objects per type of landscape were selected depending on the density of the river network. In other regions, studies were carried out along with the study of other wetland ecosystems. In all studied regions, one route per water object was made. In the field, photographs of plants and their communities were taken, floristic lists were compiled and the main hydrochemical parameters were measured (water temperature, $\mathrm{pH}$ and TDS). The studies of the macrophyte community composition were conducted both purposefully and along with the studies of other groups of aquatic organisms. Macrophyte samples were collected; they are currently stored and being registered in the Herbaria of Mire Research Group, Papanin Institute for Biology of Inland Waters Russian Academy of Sciences (coded MIRE) and Vologda State University (coded VO). More than 1000 macrophyte specimens were collected in total.

Quality control: The data were collected and identified by scientists from the Papanin Institute for Biology of Inland Waters Russian Academy of Sciences (IBIW RAS). The accuracy of determination of some samples was confirmed by experts from the Institute of Biology of Komi Scientific Centre of the Ural Branch of the Russian Academy of Sciences and Institute of Biology of Karelian Research Centre of the Russian Academy of Sciences

Step description: Research problem formulation.

Logistic issues resolution, including the choice of routes, water objects, time and duration of work.

Field stage: obtaining samples and other original materials on the flora of rivers and streams. In the field, pictures of plants and floristic lists were taken, some species were collected in a herbarium; several hydrochemical parameters (water temperature, total dissolved solids, $\mathrm{pH}$ and electrical conductivity) were measured using portable devices (Philippov et al. 2017). 
Data collection: analysis of samples not identified in the field or verification of the identification data by the experts. The keys by Tzvelev (2000), Ignatov and Ignatova (2003), Ignatov and Ignatova (2004), Lisitsyna et al. (2009) and Maevskii (2014) were used in the study. Herbarium materials were transferred for processing to the Herbarium of the Mire Research Group of Papanin Institute for Biology of Inland Waters Russian Academy of Sciences (MIRE).

Records list compilation. The dataset field names were chosen according to Darwin Core (Wieczorek et al. 2012). Georeferencing was made by fixing the coordinates of the middle part of the studied river site using a GPS navigator or Google maps. Coordinates accuracy was set to the fourth digit. In all cases, the WGS-84 coordinate system was used.

\section{Geographic coverage}

Description: The studies were carried out in various parts of European Russian and Western Siberia, mainly in the southern and middle taiga and a lesser number in the northern taiga and the forest-steppe. The analysed watercourses belong to five drainage basins: the Azov Sea, the Baltic Sea, the White Sea, the Caspian Sea and the Kara Sea. The coordinates of the northernmost site were $64.5729 \mathrm{~N}, 43.2959 \mathrm{E}$, the southernmost site $51.8139 \mathrm{~N}, 39.3836 \mathrm{E}$, the westernmost site $58.4353 \mathrm{~N}, 33.2828 \mathrm{E}$ and the easternmost site $60.8691 \mathrm{~N}, 76.4263 \mathrm{E}$ (Fig. 1).

Some examples of the studied rivers are given below (Figs 2, 3, 4, 5, 6).

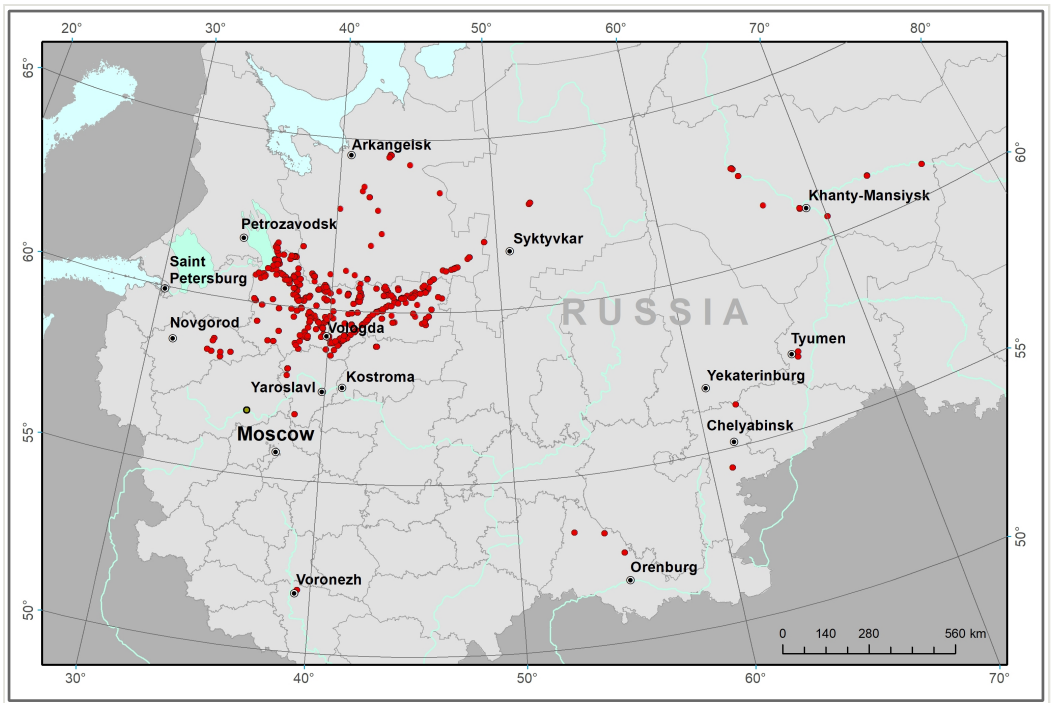

Figure 1. doi

Study area and occurrences localities (red circles). The map was constructed using ArcGis 10 software. 


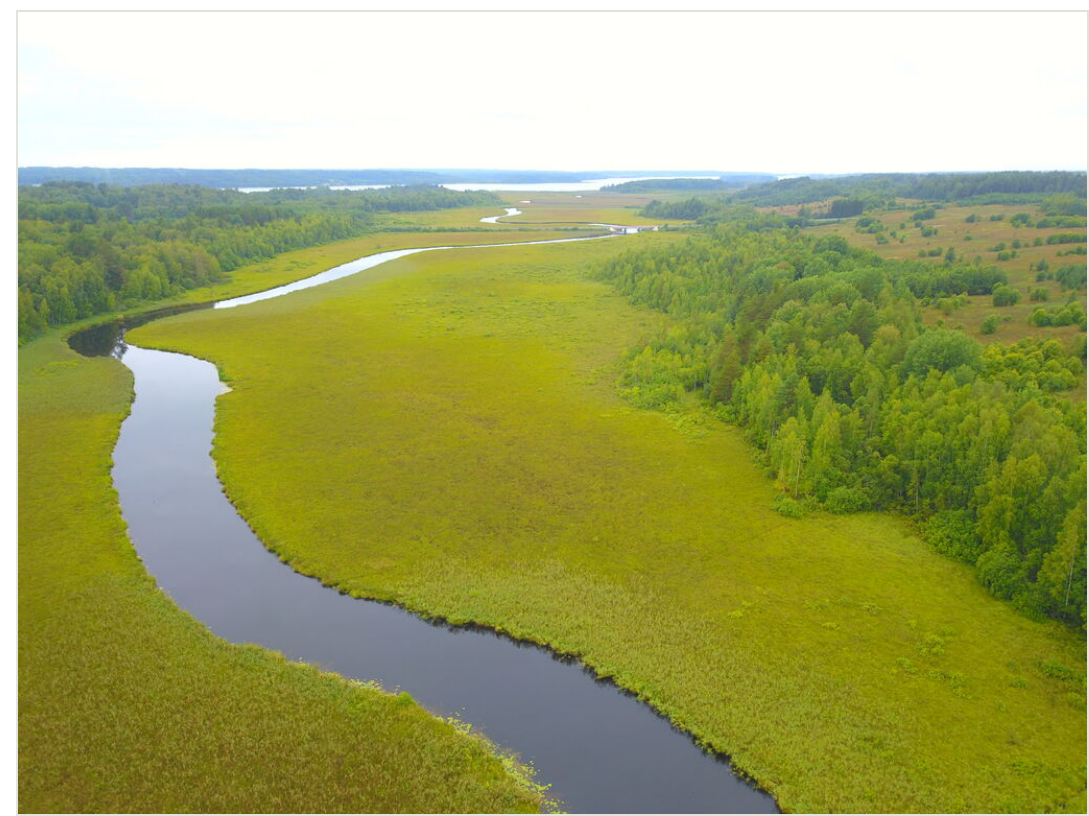

Figure 2. doi

lleksa River passing through the eutrophic mire (Vologda Region, Russia). Photo by Dmitriy A. Philippov (2019).

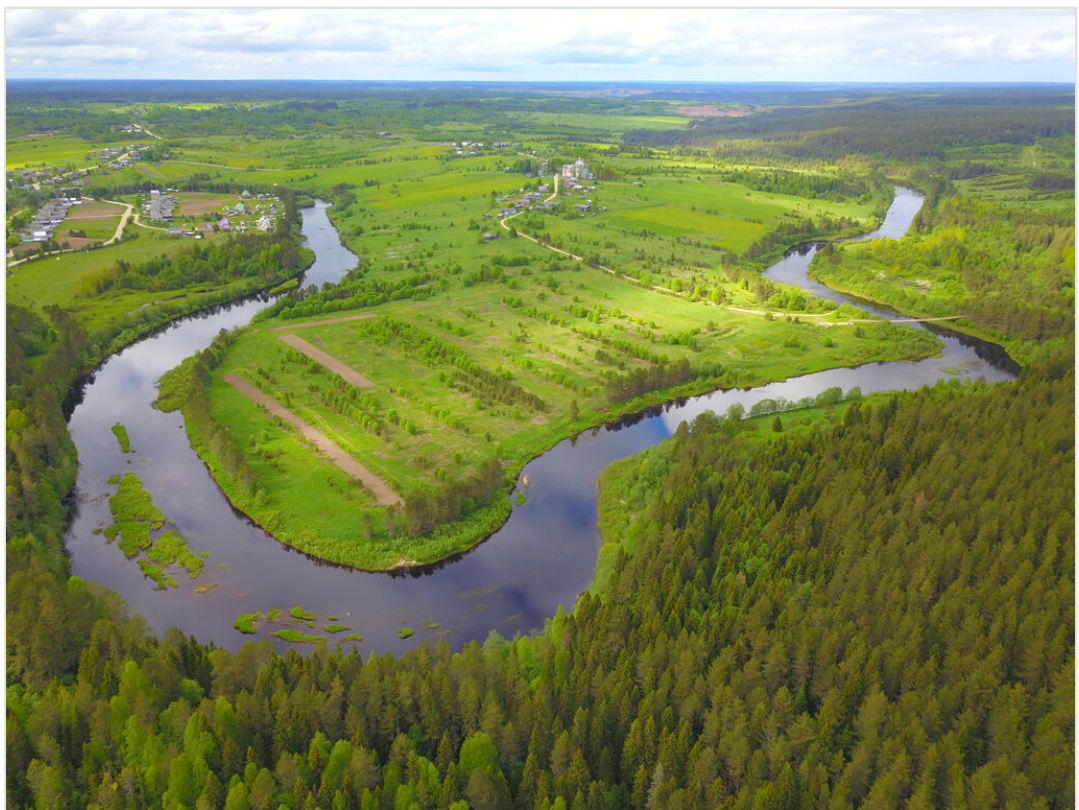

Figure 3. doi

Vaga River flowing in upland (Vologda Region, Russia). Photo by Dmitriy A. Philippov (2021). 


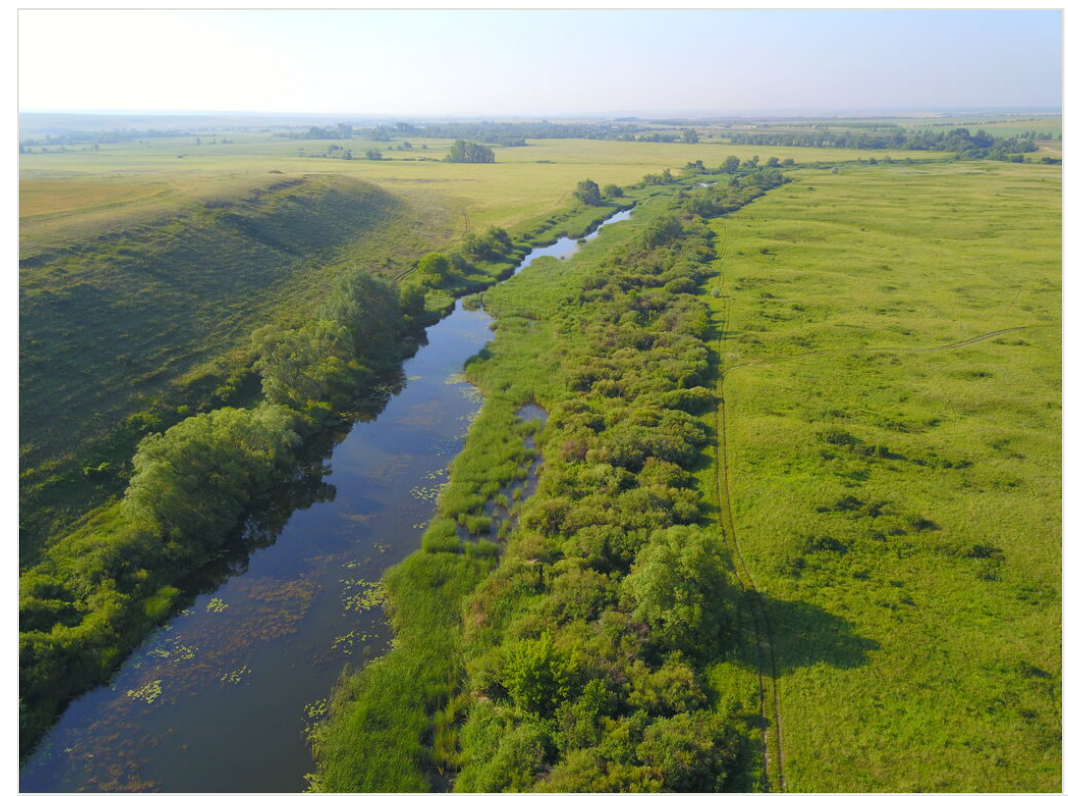

Figure 4. doi

Salmysh River flowing in the forest-steppe (Orenburg Region, Russia). Photo by Dmitriy A. Philippov (2021).

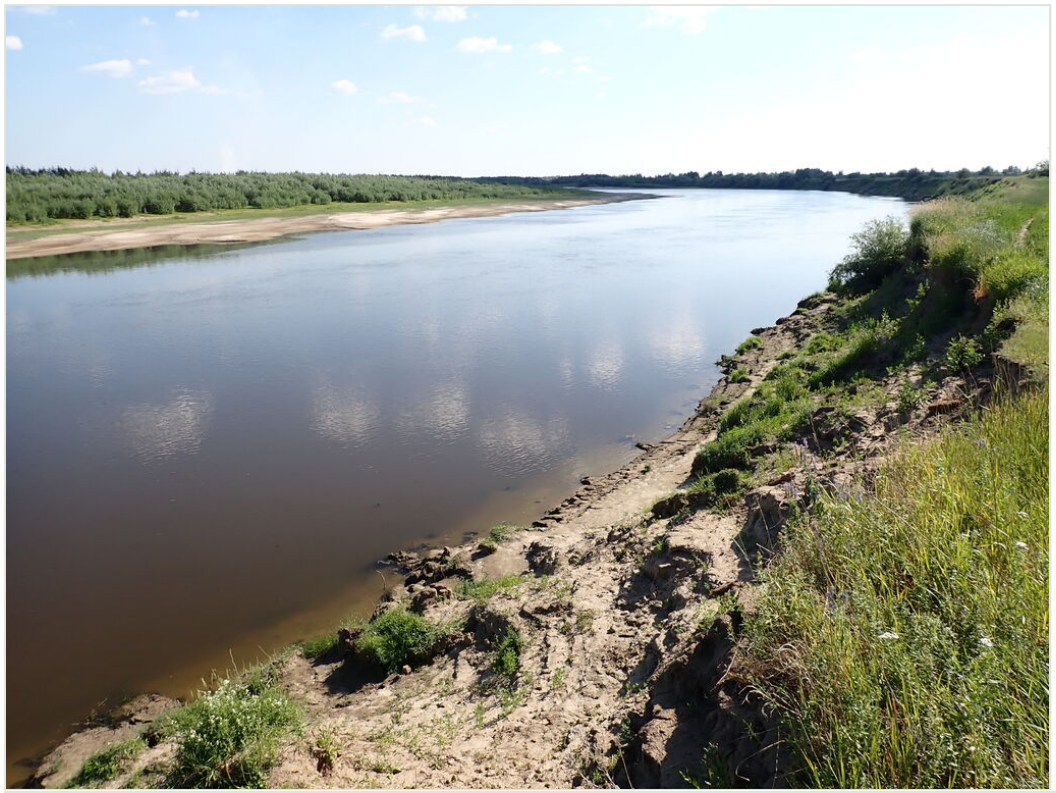

Figure 5. doi

Tura River flowing in the West Siberian Plain (Tyumen Region, Russia). Photo by Dmitriy A. Philippov (2021). 


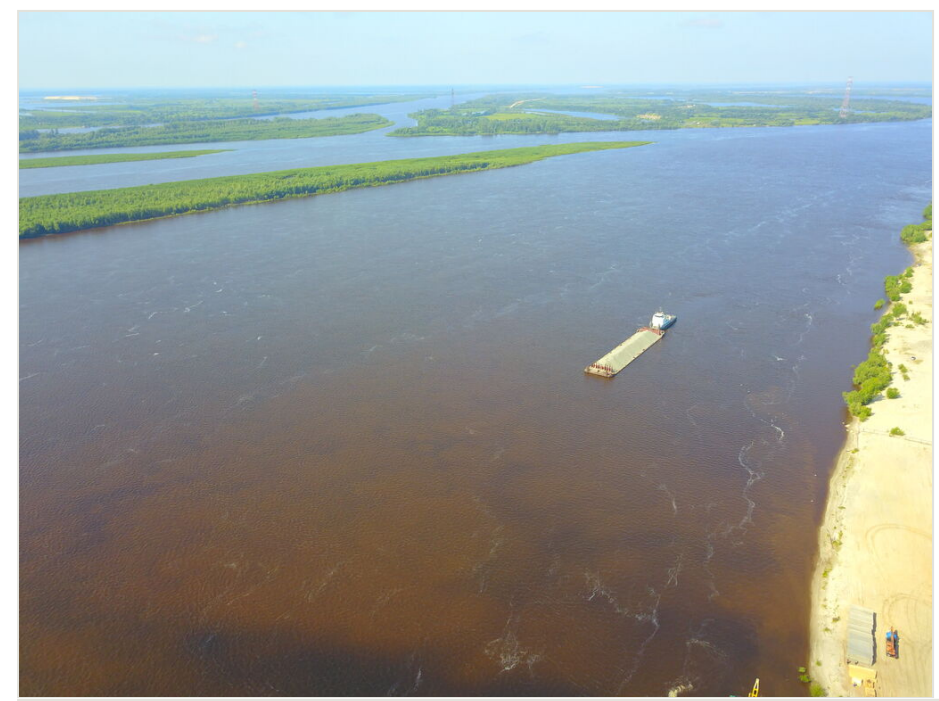

Figure 6. doi

Ob River in Surgut City (Khanty-Mansi Autonomous Okrug, Russia). Photo by Dmitriy A. Philippov (2021).

Coordinates: 51.814 and 64.573 Latitude; 33.283 and 76.426 Longitude.

\section{Taxonomic coverage}

Description: The dataset contains 292 taxa of Tracheophyta, Bryophyta, Marchantiophyta, Chlorophyta, Charophyta, Ochrophyta, Rhodophyta, including 280 lower-rank taxa (species, subspecies, varieties) and 12 taxa identified to the genus level.

\section{Taxa included:}

\begin{tabular}{|l|l|}
\hline Rank & Scientific Name \\
\hline kingdom & Chromista \\
\hline phylum & Ochrophyta \\
\hline kingdom & Plantae \\
\hline phylum & Tracheophyta \\
\hline phylum & Marchantiophyta \\
\hline phylum & Bryophyta \\
\hline phylum & Chlorophyta \\
\hline phylum & Charophyta \\
\hline kingdom & Rhodophyta \\
\hline
\end{tabular}




\section{Temporal coverage}

Notes: 2005 to 2021

\section{Usage licence}

Usage licence: Other

IP rights notes: This work is licensed under a Creative Commons Attribution (CC-BY) 4.0 Licence.

\section{Data resources}

Data package title: Data on macrophyte diversity in rivers and streams of the Vologda Region and several other regions of Russia.

Resource link: https://www.gbif.org/dataset/1c52ce65-b940-4bb8-8666-3025e58ef9ed

Alternative identifiers: http://gbif.ru:8080/ipt/resource?r=rivers and streams

\section{Number of data sets: 1}

Data set name: Data on macrophyte diversity in rivers and streams of the Vologda Region and several other regions of Russia.

Character set: Occurrence dataset

Download URL: https://www.gbif.org/dataset/1c52ce65-b940-4bb8-8666-3025e

\section{$\underline{58 e f 9 e d}$}

\section{Data format: Darwin Core}

Data format version: 1.1

Description: The dataset contains the authors' materials on macrophyte diversity (macroscopic plants regardless of their taxonomic position) in rivers and streams of East European Russia and Western Siberia. Overall, the dataset contains materials on Plantae (6094 occurrences: Tracheophyta - 5506, Marchantiophyta - 233, Bryophyta 196, Chlorophyta - 94, Charophyta - 49, Rhodophyta - 16) and Chromista (59 occurrences: Ochrophyta - 59) diversity. A total of 6153 occurrences (280 lower-rank taxa and 12 taxa identified to the genus level) are included in the dataset.

\begin{tabular}{|l|l|}
\hline Column label & Column description \\
\hline occurrencelD & $\begin{array}{l}\text { An identifier for the record, unique within this dataset. An abbreviation in the } \\
\text { identifier' number (MiReG__RiverPhytoDiv_xxxxx). }\end{array}$ \\
\hline
\end{tabular}




\begin{tabular}{|c|c|}
\hline basisOfRecord & $\begin{array}{l}\text { The specific nature of the data record in standard label of one of the Darwin Core. } \\
\text { A constant ("HumanObservation"). }\end{array}$ \\
\hline scientificName & The full scientific name, with authorship and date information, if known. \\
\hline eventDate & The date when the occurrence was recorded. \\
\hline taxonRank & The taxonomic rank. \\
\hline kingdom & The full scientific name of the kingdom in which the taxon is classified. \\
\hline phylum & The full scientific name of the phylum or division in which the taxon is classified. \\
\hline class & The full scientific name of the class in which the taxon is classified. \\
\hline order & The full scientific name of the order in which the taxon is classified. \\
\hline family & The full scientific name of the family in which the taxon is classified. \\
\hline genus & The full scientific name of the genus in which the taxon is classified. \\
\hline habitat & $\begin{array}{l}\text { A category or description of the habitat in which the occurrence was recorded (river } \\
\text { or stream). }\end{array}$ \\
\hline decimalLatitude & $\begin{array}{l}\text { The geographic latitude in decimal degrees of the geographic centre of the data } \\
\text { sampling place. }\end{array}$ \\
\hline decimalLongitude & $\begin{array}{l}\text { The geographic longitude in decimal degrees of the geographic centre of the data } \\
\text { sampling place. }\end{array}$ \\
\hline geodeticDatum & $\begin{array}{l}\text { The ellipsoid, geodetic datum or spatial reference system (SRS) upon which the } \\
\text { geographic coordinates given in decimalLatitude and decimalLongitude are based. } \\
\text { A constant ("WGS84"). }\end{array}$ \\
\hline coordinateUncertaintyInMetres & The maximum uncertainty distance in metres (30-500 m range). \\
\hline coordinatePrecision & $\begin{array}{l}\text { A decimal representation of the precision of the coordinates given in the } \\
\text { decimalLatitude and decimalLongitude. A constant ("0.0001"). }\end{array}$ \\
\hline countryCode & $\begin{array}{l}\text { The standard code for the Russian Federation according to ISO 3166-1-alpha-2 } \\
\text { (RU). }\end{array}$ \\
\hline country & Country name (Russian Federation). \\
\hline stateProvince & $\begin{array}{l}\text { The name of the next smaller administrative region than country ("oblast", } \\
\text { "avtonomniy okrug", "respublica", "kray", "region") in which the location occurs. A } \\
\text { variable (for example, "Vologda Region"). }\end{array}$ \\
\hline county & $\begin{array}{l}\text { District ('rayon', in Russian administrative subdivision system) name. The second- } \\
\text { level administrative division. }\end{array}$ \\
\hline locality & $\begin{array}{l}\text { The specific description of the place. This term may contain information modified } \\
\text { from the original to correct perceived errors or standardise the description. A } \\
\text { variable (names of rivers or springs). }\end{array}$ \\
\hline year & $\begin{array}{l}\text { The four-digit year in which the Event occurred, according to the Common Era } \\
\text { Calendar. }\end{array}$ \\
\hline
\end{tabular}




\begin{tabular}{|l|l|}
\hline month & The integer month in which the Event occurred. \\
\hline day & The integer day of the month on which the Event occurred. \\
\hline recordedBy & List of persons who collected field data. \\
\hline identifiedBy & A person who assigned the Taxon to the subject. \\
\hline dateldentified & The date when the taxonomic identification happened. \\
\hline associatedReferences & List of literature references associated with the occurrences (articles). \\
\hline acceptedNameUsage & The full name, with authorship and date information, if known, of accepted taxon. \\
\hline taxonomicStatus & The taxonomic status of a taxon. A variable (accepted or synonym). \\
\hline
\end{tabular}

\section{Additional information}

The data were collected on 247 rivers and 32 streams of East European Russia and Western Siberia and included 6153 occurrences of macrophytes (280 lower-rank taxa and 12 taxa identified to the genus level).

These studies have been conducted since 2005. From 8 to 1404 occurrences were registered each year (Fig. 7). The most productive years in respect to macrophyte studies in rivers and streams were 2011, 2013, 2017, 2018, 2020 and 2021. In any given year, the greatest emphasis was on rivers, not streams.

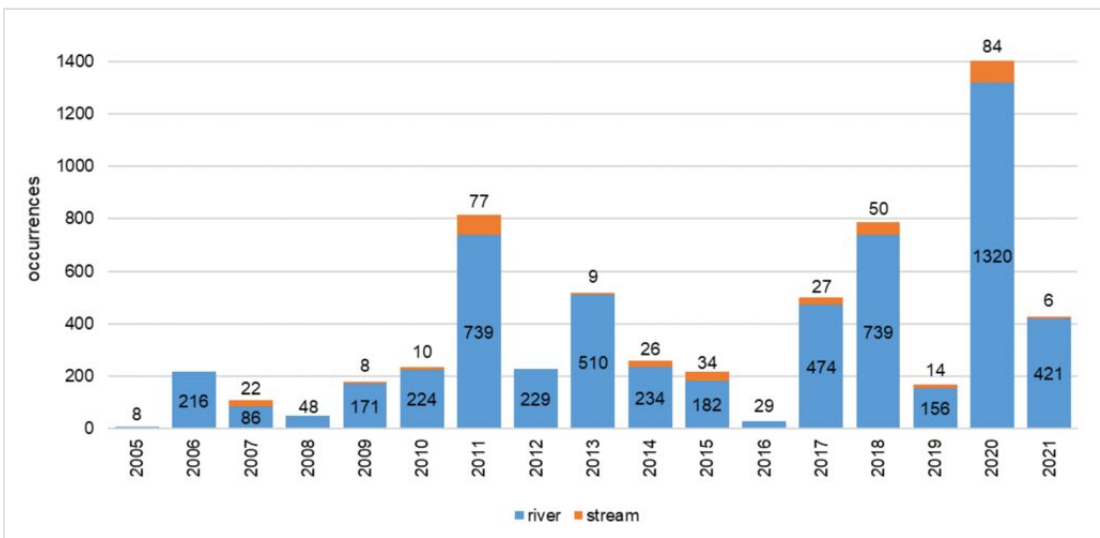

Figure 7. doi

Distribution of macrophyte occurrences in rivers and streams from 2005 to 2021.

The studies were conducted in 13 administrative regions of Russia (Table 1). The greatest number of water objects were investigated in the Vologda Region (190 rivers and 26 streams). In the Arkhangelsk Region, 30 rivers and streams were studied; in other 11 administrative regions, from 1 to 7 rivers and streams. Therefore, the most occurrences and lower-rank taxa records came from the Vologda Region (5201 and 266, respectively). 
Table 1.

Number of occurrences and taxa of macrophytes in rivers and streams in the studied regions.

\begin{tabular}{|c|c|c|c|}
\hline Region & $\begin{array}{l}\text { Number of rivers and } \\
\text { streams }\end{array}$ & $\begin{array}{l}\text { Number of } \\
\text { occurrences }\end{array}$ & $\begin{array}{l}\text { Number of lower-rank } \\
\text { taxa }\end{array}$ \\
\hline Arkhangelsk Region & 30 & 347 & 116 \\
\hline Chelyabinsk Region & 1 & 22 & 22 \\
\hline $\begin{array}{l}\text { Khanty-Mansi Autonomous } \\
\text { Okrug }\end{array}$ & 5 & 159 & 53 \\
\hline Komi Republic & 3 & 28 & 14 \\
\hline Kostroma Region & 1 & 41 & 30 \\
\hline Novgorod Region & 7 & 97 & 50 \\
\hline Orenburg Region & 3 & 26 & 23 \\
\hline Republic of Karelia & 7 & 31 & 15 \\
\hline Sverdlovsk Region & 7 & 29 & 29 \\
\hline Tyumen Region & 2 & 18 & 17 \\
\hline Vologda Region & 216 & 5201 & 266 \\
\hline Voronezh Region & 1 & 22 & 22 \\
\hline Yaroslavl Region & 4 & 132 & 61 \\
\hline All regions & 287 & 6153 & 280 \\
\hline
\end{tabular}

On average, $22 \pm 1.4$ occurrences (from 1 to 176 ) came from each given water object. Almost half of all occurrences (48.9\%) were registered on 50 rivers (Table 2 ).

Table 2.

Top 50 rivers by the number of macrophyte occurrences amongst the 279 studied rivers and streams of Russia.

\begin{tabular}{|l|l|l|}
\hline River & Region & Number of occurrences \\
\hline Syamzhena River & Vologda Region & 176 \\
\hline Kostyuga-1 River & Vologda Region & 138 \\
\hline Indomanka River & Vologda Region & 119 \\
\hline Vologda River & Vologda Region & 118 \\
\hline Kema River & Vologda Region & 110 \\
\hline Ob River & Khanty-Mansi Autonomous Okrug & 108 \\
\hline Svid' River & Arkhangelsk Region & 99 \\
\hline Soyda River & Vologda Region & 95 \\
\hline
\end{tabular}




\begin{tabular}{|c|c|c|}
\hline River & Region & Number of occurrences \\
\hline Andoma River & Vologda Region & 88 \\
\hline Vozhega River & Vologda Region & 88 \\
\hline Vaga River & Vologda Region & 76 \\
\hline Il'd River & Yaroslavl Region & 74 \\
\hline Bol'shoy Pungul River & Vologda Region & 72 \\
\hline Ileksa River & Vologda Region & 67 \\
\hline Uftyuga River (= tarnogskaya Uftyuga River) & Vologda Region & 67 \\
\hline Ukhtomka River & Vologda Region & 67 \\
\hline Votcha River & Vologda Region & 63 \\
\hline Iksoma River & Vologda Region & 57 \\
\hline Nyuksha River & Vologda Region & 55 \\
\hline Tagazhma River & Vologda Region & 54 \\
\hline Palaya River & Vologda Region & 53 \\
\hline Sora River & Vologda Region & 53 \\
\hline Koloshma River & Vologda Region & 50 \\
\hline Uftyuga River (= nyuksenskaya Uftyuga River) & Vologda Region & 50 \\
\hline Chernyy Shingar' River & Vologda Region & 49 \\
\hline Kubena River & Vologda Region & 49 \\
\hline Bol'shaya Salanga River & Vologda Region & 47 \\
\hline Povreka River & Vologda Region & 45 \\
\hline Il'chuga River & Vologda Region & 44 \\
\hline Kokshen'ga River & Vologda Region & 42 \\
\hline Kikht' River & Vologda Region & 42 \\
\hline Komyola River & Vologda Region & 41 \\
\hline Uskala River & Vologda Region & 41 \\
\hline Vocha River & Kostroma Region & 41 \\
\hline Pes'ya Den'ga River & Vologda Region & 40 \\
\hline Strel'na River & Vologda Region & 40 \\
\hline Sheybukhta River & Vologda Region & 38 \\
\hline Pinega River & Arkhangelsk Region & 37 \\
\hline Pocha River & Vologda Region & 37 \\
\hline Megra River & Vologda Region & 36 \\
\hline Ukhtomitsa River (= kirillovskaya Ukhtomitsa River) & Vologda Region & 36 \\
\hline
\end{tabular}




\begin{tabular}{|l|l|l|}
\hline River & Region & Number of occurrences \\
\hline Bol'shaya Runga River & Vologda Region & 35 \\
\hline Chuzhga River & Vologda Region & 35 \\
\hline Kiuy River & Vologda Region & 35 \\
\hline Okhotka River & Vologda Region & 35 \\
\hline Nerel' River & Yaroslavl Region & 34 \\
\hline Suda River & Vologda Region & 34 \\
\hline Chundruchey River & Vologda Region & 33 \\
\hline Kovzha River & Vologda Region & 33 \\
\hline Yema River & Vologda Region & 33 \\
\hline Total & & 3009 \\
\hline
\end{tabular}

The studies have provided data on the locations of a number of rare macrophyte species. For example, in the Vologda Region, 32 species listed in the Red Data Book of the Vologda Region (Suslova et al. 2013, Anonymous 2015) were registered, including 15 protected species: Critically Endangered (CR) - Batrachium penicillatum, Endangered (EN) Potamogeton crispus, Vulnerable (VU) - Batrachium circinatum, Carex atherodes, Carex elata subsp. omskiana (Meinsh.) Jalas [as C. omskiana (Meinsh.) Jalas], Riccia canaliculata, Near Threatened (NT) - Aegagropila linnaei, Molinia coerulea, Tolypella prolifera, Least Concern (LC) - Carex pseudocyperus, Chara virgata, Equisetum variegatum, Hygroamblystegium fluviatile, Nitella syncarpa, Senecio paludosus subsp. lanatus [as $S$. tataricus Less.] and 17 species assigned with the status "biological control required": Batrachium eradicatum, Batrachium trichophyllum, Chara tomentosa, Eleocharis uniglumis, Humulus lupulus, Hydrocharis morsus-ranae, Iris pseudacorus, Nymphaea candida, Potamogeton berchtoldii, Potamogeton filiformis, Rumex hydrolapathum, Scapania subalpina, Scolochloa festucacea, Sparganium natans, Stratiotes aloides, Typha angustifolia and Utricularia intermedia.

\section{Acknowledgements}

We are grateful to our colleagues who took part in the field studies, especially Vasiliy A. Philippov. We also thank the colleagues who helped with the taxonomic identification of some specimens, especially A.A. Bobrov and V.S. Vishnyakov (IBIW RAS, Borok), M.A. Boychuk (IB KarRC RAS, Petrozavodsk), M.V. Dulin (IB Komi SC UB RAS, Syktyvkar) and A.N. Levashov (Center of Creativity, Vologda). We are grateful to Igor V. Filonenko (VNIRO, Vologda) for his help with construction of a map. We express our deep gratitude to Natalya Ivanova (Institute of Mathematical Problems of Biology RAS, Pushchino) for her help with the dataset publication and editing. 
This research was funded by the Tyumen Oblast Government, as part of the West-Siberian Interregional Science and Education Center's project No. 89-DON (2) and was carried out within the framework of a State Assignment to IBIW RAS no. 121051100099-5.

We thank the Global Biodiversity Information Facility in collaboration with the Finnish Biodiversity Information Facility and Pensoft Publishers for providing the opportunity to publish this paper in the "Biota of Russia" collection.

\section{Author contributions}

DAP: Conceptualisation, Investigation, Resources, Data Curation, Writing - Original Draft, Writing - Review \& Editing, Project administration; ASK: Investigation, Formal analysis, Visualisation, Writing - Original Draft.

\section{References}

- $\quad$ Abolin AA, Andreeva EN, Afonina OM, Badmaeva NK, Bakalin VA, Belkina OA, Borovichev EA, Chemeris EV, Cherdantseva VY, Cherednichenko OV, Czernyadjeva IV, Doroshina GY, Dulin MV, Ibatullin AA, Ignatov MS, Ignatova EA, Kokoshnikova YS, Konstantinova NA, Kotseruba VV, Malashkina EV, Mamontov YS, Notov AA, Opmanis AG, Philippov DA, Potemkin AD, Reriha IS, Shestakova AA, Shilnikov DS, Sofronova EV, Susko UA, Teleganova VV, Tubanova DY (2011) New records. Arctoa 20: 247-268. [In Russian]. https://doi.org/10.15298/arctoa.20.20

- Afonina OM, Akatova TV, Baisheva EZ, Belkina OA, Bezgodov AG, Borovichev EA, Czernyadjeva IV, Boychuk MA, Doroshina GY, Dulin MV, Fedosov VE, Ignatov MS, Ignatova EA, Konstantinova NA, Krivobokov LV, Kučera J, Kushnevskaja EV, Maksimov Al, Maksimova TA, Mamontov YS, Notov AA, Philippov DA, Potemkin AD, Ryazanova DT, Schilnikov DS, Savchenko AN, Sofronov RR, Sofronova EV, Tubanova DY, Urbanavichene IN, Urbanavichyus GP, Volkova EM, Zheleznova GV (2010) New records. Arctoa 19: 259-288. [In Russian]. https://doi.org/10.15298/arctoa.19.24

- $\quad$ Anonymous (2015) Resolution of the Government of Vologda Region from 24.02.2015 №125 «On approval of list of rare and endangered species (intraspecific taxa) plants and fungi, which feature in the Red Data Book of Vologda Region». Government of Vologda Region. Постановление Правительства Вологодской области №125 от 24.02.2015 «Об утверждении перечня (списка) редких и исчезающих видов (внутривидовых таксонов) растений и грибов, занесённых в Красную книгу Вологодской области». URL: https://vologda-oblast.ru/dokumenty/393552/

- $\quad$ Biggs BJ (1996) Hydraulic habitat of plants in streams. River Research and Applications 12 (2-3): 131-144. https://doi.org/10.1002/(SICl)1099-1646(199603)12:2/33.0.CO;2-X

- Bobrov AA, Philippov DA (2012) Myriophyllum sibiricum (Haloragaceae) in Vologda region. Vestnik of Saint Petersburg University. Biology 2: 25-30. [In Russia].

- $\quad$ Carpenter SR, Lodge DM (1986) Effects of submersed macrophytes on ecosystem processes. Aquatic Botany 26: 341-370. https://doi.org/10.1016/0304-3770(86)90031-8 
- $\quad$ Chambers PA, Lacoul P, Murphy KJ, Thomaz SM (2008) Global diversity of aquatic macrophytes in freshwater. Hydrobiologia 595 (1): 9-26. https://doi.org/10.1007/ s10750-007-9154-6

- $\quad$ Chemeris EV, Bobrov AA (2013) Aegagropila linnaei (Cladophoraceae, Chlorophyta) in rivers of the northern European Russia. Botanicheskii Zhurnal 98 (10): 1201-1211. [In Russian].

- $\quad$ Chemeris EV, Bobrov AA, Philippov DA (2013) Stoneworts (Charophyta) of watercourses in Vologda region. Vestnik of Saint Petersburg University. Biology 1: 45-53. [In Russian].

- $\quad$ Chernova AM, Philippov DA (2019) Stocks of Nuphar lutea (L.) Sm. in small river Ild (Yaroslavl Region, Russia). Field Biologist Journal 1 (4): 209-217. [In Russian]. https://doi.org/10.18413/2658-3453-2019-1-4-209-217

- Chernova AM, Czhobadze AB, Levashov AN, Philippov DA (2019) Flora of waterbodies of the Volga River Basin: additions and updates on the Vologda Region, Russia. Samarskaya Luka: problems of regional and global ecology 28 (1): 40-54. [In Russian]. https://doi.org/10.24411/2073-1035-2018-10180

- $\quad$ Clarke SJ, Wharton G (2001) Sediment nutrient characteristics and aquatic macrophytes in lowland English rivers. The Science of the Total Environment 266 (1): 103-112. https://doi.org/10.1016/s0048-9697(00)00754-3

- Dulin MV, Philippov DA, Karmazina EV (2009) Current state of knowledge of the liverwort and hornwort flora of the Vologda Region, Russia. Folia Cryptogamica Estonica 45: 13-22.

- Dulin MV, Philippov DA (2010) Additions to the liverworts flora of the Vologda Region. Herald of Tver State University. Series: Biology and Ecology 17-16: 103-107. [In Russian].

- European Commision (2000) Directive 2000/60/EC of the European Parliament and of the Council of 23 October 2000 establishing a framework for the community action in the field of water policy. Official Journal of the European Commission - Legis 327: 1-72. URL: https://eur-lex.europa.eu/legal-content/EN/TXT/?uri=celex\%3A32000L0060

- Grenouillet G, Pont D, Seip KL (2002) Abundance and species richness as a function of food resources and vegetation structure: juvenile fish assemblages in rivers. Ecography 25 (6): 641-650. https://doi.org/10.1034/j.1600-0587.2002.250601.x

- Gurnell AM, van Oosterhout MP, de Vlieger B, Goodson JM (2006) Reach-scale interactions between aquatic plants and physical habitat: River Frome, Dorset. River Research and Applications 22 (6): 667-680. https://doi.org/10.1002/rra.929

- Horvath TG (2004) Retention of particulate matter by macrophytes in a first-order stream. Aquatic Botany 78 (1): 27-36. https://doi.org/10.1016/j.aquabot.2003.09.003

- Ignatov MS, Ignatova EA (2003) Moss flora of the Middle European Russia. Vol. 1: Sphagnaceae - Hedwigiaceae. Arctoa 11 (s1): 1-608. [In Russian].

- Ignatov MS, Ignatova EA (2004) Moss flora of the Middle European Russia. Vol. 2: Fontinalaceae - Amblystegiaceae. Arctoa 11 (s2): 609-960. [In Russian].

- Ivicheva KN, Makarenkova NN, Zaytseva VL, Philippov DA (2018) Influence of flow velocity, river size, a dam, and an urbanized area on biodiversity of lowland rivers. Biosystems Diversity 26 (4): 292-302. https://doi.org/10.15421/011844

- $\quad$ Lisitsyna LI, Papchenkov VG, Artemenko VI (2009) Флора водоёмов волжского бассейна. Определитель сосудистых растений. [Flora of water bodies of the Volga 
river basin. Identification guide of vascular plants]. KMK Scientific Press Ltd., Moscow, 219 pp. [In Russian]. [ISBN 978-5-87317-554-3]

- Maevskii PF (2014) Флора средней полосы европейской части России. [Flora of Middle Part of European Russia]. 11th. KMK Scientific Press Ltd., Moscow, 635 pp. [In Russian]. [ISBN 978-5-87317-958-9]

- Papchenkov VG, Scherbakov AV, Lapirov AG (2003) Основные гидроботанические понятия и сопутствующие им термины: Проект. [Basic hydrobotanical concepts and associated terms: project]. Servis Press, Ryazan, 21 pp. [In Russian].

- $\quad$ Philippov DA, Prokin AA, Przhiboro AA (2017) Методы и методики гидробиологического исследования болот: учебное пособие. [Methods and methodology of hydrobiological study of mires: tutorial]. University of Tyumen Publishing, Tyumen, 207 pp. [In Russian]. [ISBN 978-5-400-01377-5]

- Philippov DA, Komarova AS (2021) Data on macrophyte diversity in rivers and streams of the Vologda Region and several other regions of Russia. 1.1. Papanin Institute for Biology of Inland Waters Russian Academy of Sciences. Release date: 2021-10-22. URL: https://www.gbif.org/dataset/1c52ce65-b940-4bb8-8666-3025e58ef9ed

- Shabunov AA, Philippov DA (2014) Rare vascular plants and vertebrate animals findings in the southern part of Gryazovets district: additions to Vologda Region Red book. Vestnik of Kostroma State University 20 (3): 20-26. [In Russian].

- Sofronova EV, Abakarova AS, Afonina OM, Badmaeva NK, Borovichev EA, Boychuk MA, Czernyadjeva IV, Doroshina GY, Dulin MV, Dyachenko AP, Fedosov VE, Ibatullin AA, Ignatov MS, Ignatova EA, Ivanova EI, Ivchenko TG, Kokoshnikova YS, Kozhin MN, Kuzmina EY, Maksimov AI, Maksimova TA, Malashkina EV, Mamontov YS, Moshkovskii SA, Notov AA, Philippov DA, Potemkin AD, Pisarenko OY, Preobrazhenskaja ES, Shafigullina NR, Taran GS, Teleganova VV, Teplov KY, Terentyeva EV, Tubanova DY, Zheleznova GV (2012) New bryophyte records. 1. Arctoa 21: 275-300. [In Russian]. https://doi.org/10.15298/arctoa.21.27

- Sofronova EV, Abdurachmanova ZI, Afonina OM, Akatova TV, Andrejeva EN, Bakalin VA, Bezgodov AG, Borovichev EA, Czernyadjeva IV, Doroshina GY, Dulin MV, Fedosov VE, Golovina EO, Ignatov MS, Ignatova EA, Kotkova VM, Kozhin MN, Kučera J, Kurbatova LE, Kushnevskaya EV, Leushina EG, Makarova MA, Maksimova AY, Nikolajev IA, Philippov DA, Popova NN, Potemkin AD, Prelovskaya ES, Teleganova VV, Vilnet AA, Volkova EM, Zolotukhin NI (2015) New bryophyte records. 5 . Arctoa 24 (2): 584-609. [In Russian]. https://doi.org/10.15298/arctoa.24.51

- Suslova TA, Czhobadze AB, Philippov DA, Shiryaeva OS, Levashov AN (2013) A second edition of the Red Data Book of the Vologda Region: revisions in the lists of protected and biological control required species of plants and fungi. Phytodiversity of Eastern Europe 7 (3): 93-104. [In Russian]. https://doi.org/10.24411/2072-

8816-2013-10022

- Tzvelev NN (2000) Определитель сосудистых растений Северо-Западной России (Ленинградская, Псковская и Новгородская области). [Manual of the vascular plants of North-West Russia (Leningrad, Pskov and Novgorod provinces)]. St.-Petersburg State Chemical-Pharmaceutical Academy Press, Saint Petersburg, 781 pp. [In Russian]. [ISBN 5-8085-0077-X]

- Vishnyakov VS, Philippov DA (2018) New records of charophytes (Charales) from the Northern European Russia. Botanicheskii Zhurnal 103 (8): 1016-1031. [In Russian]. https://doi.org/10.7868/S0006813618080070 
- Vishnyakov VS, Romanov RE, Chemeris EV, Kipriyanova LM, Chernova AM, Komarova AS, Philippov DA (2020) New records of Vaucheria (Ochrophyta, Xanthophyceae) in Russia. Novosti Sistematiki Nizhshikh Rastenii 54 (1): 7-41. [In Russian]. https://doi.org/ 10.31111/nsnr/2020.54.1.7

- Vishnyakov VS, Romanov RE, Komarova AS, Belyakov EA, Moseev DS, Churakova EY, Czhobadze AB, Philippov DA (2021) New charophyte records (Characeae) in European Russia. Botanicheskii Zhurnal 106 (1): 61-76. [In Russian]. https://doi.org/ 10.31857/S0006813621010117

- Wieczorek J, Bloom D, Guralnick R, Blum S, Döring M, Giovanni R, Robertson T, Vieglais D (2012) Darwin Core: An evolving community-developed biodiversity data standard. PLOS One 7 (1): e29715. https://doi.org/10.1371/journal.pone.0029715 